\title{
IMPLEMENTATION OF DEVELOPMENT AND REGISTRATION AND ELIMINATION \\ ACCEPTANCES OF RIGHTS BASED ON LAW NUMBER 4 YEAR 1996 REGARDING RIGHTS OF RESPONSIBILITY
}

\section{YUNIMAR}

Volume 1 Nomor 1

JILP

ISSN: 2581-0804

E-ISSN: 2581-1819

\section{ABSTRACT}

Mortgage right are the security rights imposed on land rights. On April 9, 1996, Law Number 4 of 1996 was enacted on the Land and Property Rights related to the land, or more briefly referred to as UUHT (Law on Mortgage Rights). UUHT seeks to provide legal certainty and protection to all parties in utilizing the land as an object of Mortgage Rights.

Keywords: mortgage right, law, land and property right

\section{PELAKSANAAN PEMBUATAN DAN PENDAFTARAN SERTA PENGHAPUSAN \\ AKTA PEMBERIAN HAK TANGGUNGAN BERDASARKAN UNDANG-UNDANG NOMOR 4 TAHUN 1996 TENTANG HAK TANGGUNGAN}

Hak Tanggungan adalah hak jaminan yang dibebankan pada hak atas tanah. Pada tanggal 9 April 1996 diundangkan UU Nomor 4 Tahun 1996 tentang Hak Tanggungan atas tanah beserta benda-benda yang berkaitan dengan tanah atau lebih singkatnya disebut UUHT
(Undang-Undang Hak Tanggungan). UUHT berusaha memberi kepastian dan perlindungan hukum kepada semua pihak dalam memanfaatkan tanah sebagai obyek Hak Tanggungan.

Kata Kunci: hak tanggungan, hukum, tanah dan hak milik 


\section{PENDAHULUAN}

Pembangunan di bidang ekonomi merupakan bagian dalam pembangunan nasional sebagai salah satu upaya untuk mewujudkan masyarakat adil dan makmur berdasarkan Pancasila dan Undang-undang Dasar Negara Republik Indonesia Tahun 1945. Dalam rangka memelihara kesinambungan pembangunan, masyarakat sebagai orang perseorangan maupun badan hukum memerlukan dana, guna meningkatkan kegiatan hidup sehari-hari. Dana yang diperoleh oleh masyarakat sebagian berasal dari bank melalui kegiatan perkreditan. Disinilah peranan bank sangat dibutuhkan, karena sesuai dengan asas perbankan yaitu berasaskan demokrasi ekonomi dimana di dalam konsideran menimbang huruf (b) Undang-undang Republik Indonesia Nomor 7 Tahun 1992 sebagaimana telah diubah dengan Undang-undang Republik Indonesia Nomor 10 Tahun 1998 tentang Perbankan. Fungsi bank adalah sebagai penghimpun dan penyalur dana dari dan ke masyarakat yang memerlukannya.

Kredit yang diberikan oleh bank tentunya mengandung resiko, sehingga dalam pelaksanaannya bank harus memperhatikan asasasas perkreditan yang sehat untuk mengurangi resiko tersebut. Jaminan pemberian kredit dalam arti keyakinan atas kemampuan dan kesanggupan debitur untuk melunasi kewajibannya sesuai dengan yang diperjanjikan, merupakan faktor keyakinan tersebut. Sebelum memberikan kredit, bank harus melakukan penilaian yang seksama terhadap watak, kemampuan, modal, agunan dan prospek usaha dari debitur.

Syarat-syarat jaminan yang baik adalah :

1. Jaminan dapat segera mudah dan cepat membantu mendapatkan kredit oleh yang memerlukan kredit.

2. Jaminan tidak mengurangi atau melemahkan perbuatan si pencari kredit dalam melaksanakan tujuannya.

3. Jaminan dapat memberikan kepastian kepada si pemberi kredit, dalam arti bahwa barang jaminan tersebut setiap waktu tersedia untuk di eksekusi, bilamana perlu dapat segera di uangkan dengan cepat dapat dipakai melunasi hutang si pemberi kredit.

Jaminan yang utama di tuntut oleh kreditur yaitu jaminan terhadap benda-benda tetap khususnya tanah. Praktek jaminan yang sering digunakan pada perbankan Indonesia, adalah jaminan kebendaan yang meliputi: a. Hipotek, yaitu suatu hak kebendaan atas benda-benda tidak bergerak, untuk mengambil penggantian dari padanya bagi pelunasan suatu perikatan (Pasal 1162 KUH Perdata).

b. Credietverbang, yaitu suatu jaminan atas tanah berdasarkan Koninklijk Besluit (KB) tanggal 6 Juli 1908 Nomor 50 (stbl 1908 Nomor542).

c. $\quad$ Fiducia (fiduciare eigendomsoverdracht) yaitu pemindahan milik atas kepercayaan.

Salah satu benda tetap yang sering dijadikan objek jaminan hutang adalah tanah. Tanah merupakan barang jaminan untuk pembayaran hutang yang disukai oleh kreditur dalam memberikan pinjaman, dengan syarat:

1) Dapat dinilai oleh uang, karena hutang yang dijamin berupa uang.

2) Mempunyai sifat dapat dipindahtangankan karena apabila debitur cidera janji, benda yang dijaminkan dapat dijual.

3) Termasuk hak yang didaftar menurut peraturan tentang pendaftaran tanah yang berlaku 4) Memerlukan suatu penunjukan khusus oleh suatu undang-undang.

Hak Tanggungan merupakan suatu istilah baru untuk lembaga jaminan maupun pelaksanaan dari ketentuan undang-undang tentang adanya pranata jaminan hutang dengan tanah sebagai agunannya yang disebut Hak Tanggungan (harus dibedakan dengan istilah Pertanggungan untuk kegiatan asuransi).

Timbulnya Hak Tanggungan hanyalah dimungkinkan apabila sebelumnya telah diperjanjikan di dalam perjanjian kredit atau perjanjian hutang piutang yang dijamin Hak Tanggungan. Perjanjian kredit tersebut atau perjanjian hutang piutang tersebut dibuat baik secara dibawah tangan maupun dengan akta notaris. Sedangkan Hak Tanggungan itu sendiri dilakukan dengan pembuatan perjanjian tersendiri oleh Pejabat Pembuat akta Tanah (PPAT) atau yang disebut dengan Akta Pemberian Hak Tanggungan (Pasal 10 ayat (2) UUHT).

Pemerintah dalam memberikan pengawasan yang tepat dan cepat sehingga kredit perbankkan yang diberikan tersebut dapat berperan sebagaimana diharapkan, sehingga kemungkinan kebocoran-kebocoran dapat dihindari sedini mungkin. Adapun proses pembebanan Hak Tanggungandiatur dalam Pasal 8 ayat (1) Undang-Undang Hak Tanggungan melalui dua tahap: 
a) Tahap pemberian Hak Tanggungan dengan pembuatan Akta Pemberian Hak Tanggungan (APHT) oleh PPAT sebelumnya telah dibuat perjanjian hutang pihutang yang menjadi dasar dari Hak Tanggungan.

b) Tahap pendaftaran oleh kantor Pertanahan,pendaftaran ini adalah penting karena membuktikan saat lahirnya Hak Tanggungan yang dibebankan. Bahwa untuk memperoleh kepastian mengenai saat pendaftaran maka ditentukan bahwa selambat-lambatnya 7 (tujuh) hari setelah penandatangan Akta Pemberian Hak Tanggungan.

Setiap penciptaan hak baru, peralihan hak termasuk pembebanannya harus dapat dibuktikan dengan suatu akta, akan tetapi akta tersebut tidaklah didaftar melainkan haknya yang dilahirkan dari akta tersebut yang didaftar. Dengan demikian berarti akta hanyalah dipergunakan sebagai : "sumber data untuk memperoleh kejelasan mengenai terjadinya suatu hak, peralihan hak atau pembebanan hak".

Adanya kewajiban untuk mendaftarkan Hak Tanggungan ditujukan untuk menjamin kepastian hukum kepada pemberi dan penerima Hak Tanggungan dan untuk memberikan perlindungan hukum, manakala salah satu pihak mengadakan tindakan-tindakan yang merugikan

\section{A. Perumusan Masalah}

1. Bagaimanakah tata cara pembuatan Akta Pemberian Hak Tanggungan (APHT) yang dibuat dihadapan Pejabat Pembuat akta Tanah (PPAT) ?

2. Bagaimanakah Pelaksanaan Pendaftaran Akta Pemberian Hak Tanggungan (APHT) pada Kantor Pertanahan ?

3. Bagaimanakah

Pelaksanaan penghapusan Hak Tanggungan pada Kantor Pertanahan?

\section{B. Tujuan Penelitian}

1. Untuk mengetahui Tata Cara pembuatan Akta Pemberian Hak Tanggungan (APHT) yang dibuat dihadapan Pejabat Pembuat akta Tanah (PPAT).

2. Untuk mengetahui Pelaksanaan Pendaftaran Akta Pemberian Hak Tanggungan (APHT) pada Kantor Pertanahan.

3. Untuk mengetahui pelaksanaan Penghapusan Hak Tanggungan pada Kantor Pertanahan.

3. pihak lainnya. Sebagai contoh ketika pemberi Hak Tanggungan tidak dapat melunasi hutang yang dipinjamnya dari pemegang Hak Tanggungan, maka dengan adanya pendaftaran Hak Tanggungan, pemegang Hak Tanggungan mempunyai kekuatan hukum yang kuat untuk mendapatkan pembayaran atas piutangnya dengan cara mengeksekusi tanah yang dibebani Hak Tanggungan.

Apabila Hak Tanggungan hapus karena pelunasan hutang oleh debitur kepada kreditur, ataupun karena pelepasan Hak Tanggungan secara sukarela oleh kreditur, maka hapusnya Hak Tanggungan harus dilakukan dengan mengadakan pencoretan atau roya di Kantor Pertanahan dimana Hak Tanggungan didaftarkan, sehingga pihak ketiga mengetahui bahwa Hak Tanggungan itu sudah dihapus, jika tidak diroya maka pihak ketiga menganggap bahwa Hak Tanggungan itu masih berlaku.

Berdasarkan pemikiran yang telah diuraikan diatas, penulis tertarik untuk mengkaji lebih dalam dan mewujudkan menjadi suatu karya ilmiah dengan judul : 'Pelaksanaan Pembuatan dan Pendaftaran serta Penghapusan Akta Pemberian Hak Tanggungan (APHT) Berdasarkan UU Nomor 4 Tahun 1996 tentang Hak Tanggungan"'

\section{Kegunaan Penelitian}

1. Secara teoritis, hasil penelitian ini diharapkan dapat memberikan sumbangan pemikiran dibidang hukum khususnya hukum jaminan.

2. Secara praktis, hasil penelitian ini dapat berguna sebagai masukan dan pedoman pemerintah dalam hal ini Badan Pertanahan Nasional (BPN) dan Pejabat Pembuat akta Tanah (PPAT) guna menentukan kebijakan dan langkah-langkah yang timbul sehubungan dengan pembuatan dan pendaftaran serta penghapusan Akta Pemberian Hak Tanggungan (APHT) pada Kantor Pertanahan Kota Padang dan sebagai informasi bagi masyarakat tentang pengaruh berlakunya Undang-Undang Hak Tanggungan terhadap jaminan yang diikat dengan Akta Pemberian Hak Tanggungan (APHT). 


\section{METODE PENELITIAN}

1. Spesifikasi Penelitian

Dalam penelitian skripsi ini, spesifikasi penelitiannya adalah penelitian deskriptif, yaitu berupa penggambaran dari hal-hal tertentu yang menjadi permasalahan dalam penelitian.

2. Sumber Data

Penelitian ini hanya menggunakan data sekunder, terdiri dari bahan hukum primer, bahan hukum sekunder dan bahan hukum tersier.

a. Bahan hukum primer, terdiri dari :

1) Kitab Undang-undang Hukum Perdata (KUH Perdata).

2) Undang-undang Nomor 5 Tahun 1960 tentang Peraturan Dasar Pokok-pokok Agraria.

3) Undang-undang Nomor 4 Tahun 1996 tentang Hak Tanggungan.

4) Peraturan Pemerintah Nomor 10 Tahun 1961 juncto Peraturan Pemerintah Nomor 24 Tahun 1997 tentang Pendaftaran Tanah.

5) Peraturan Pemerintah Nomor 37 Tahun 1998 tentang Peraturan Jabatan Pembuat Akta Tanah.

\section{HASIL PENELITIAN PEMBAHASAN}

A. Tata Cara Pembuatan Akta Pemberian Hak Tanggungan (APHT) yang dibuat dihadapan Pejabat Pembuat Akta Tanah (PPAT)

Tata cara pemberian hak tanggungan diatur dalam Pasal 10 dan Pasal 15 Undang-undang Nomor 4 Tahun 1996 tentang Hak Tanggungan. Pasal 10 mengatur tentang tata cara pemberian hak tanggungan oleh pemberi hak tanggungan secara langsung, sedangkan dalam Pasal 15 mengatur tentang pemberian kuasa pembebanan hak tanggungan oleh pemberi hak tanggungan kepada penerima hak tanggungan.

Prosedur pemberian hak tanggungan dengan cara langsung adalah sebagai berikut :

1. Didahului dengan janji untuk memberikan hak tanggungan sebagai jaminan pelunasan hutang tertentu, yang merupakan tak terpisahkan dari perjanjian hutang piutang.

2. Dilakukan dengan pembuatan Akta Pemberian Hak Tanggungan (APHT) oleh Pejabat Pembuat akta Tanah (PPAT).

3. Objek hak tanggungan berupa hak atas tanah yang berasal dari konversi hak lama yang telah memenuhi syarat didaftarkan, akan tetapi b. Bahan hukum sekunder, terdiri dari :

1) Bahan literatur.

2) Hasil karya ilmiah para sarjana.

3) Jurnal.

4) Hasil penelitian dan sebagainya.

c. Bahan hukum tersier, yakni bahan yang memberikan petunjuk maupun penjelasan terhadap bahan hukum primer dan sekunder meliputi :

Kamus Hukum dan Kamus Besar Bahasa Indonesia.

3. Teknik Pengumpulan Data

Untuk memperoleh data dalam penelitian digunakan teknik penelitian pengumpulan data dengan studi dokumentasi atau studi kepustakaan.

4. Analisis dan Penyajian Data

Data yang telah terkumpul dari data sekunder atau data kepustakaan, dianalisis secara kualitatif, yaitu mengelompokkan data menurut aspek-aspek yang diteliti atau tanpa mempergunakan angka-angka, kemudian disajikan dalam bentuk deskriptif.

belum dilakukan, pemberian hak tanggungan dilakukan bersamaan dengan permohonan pendaftaran hak atas tanah yang bersangkutan.

Prosedur pembebanan hak tanggungan yang menggunakan Surat Kuasa Membebankan Hak Tanggungan (SKMHT) sebagaimana yang dimaksud dalam Pasal 15 Undang-undang Nomor 4 Tahun 1996 adalah sebagai berikut :

a. Wajib dibuatkan dengan akta Notaris atau Akta Pejabat Pembuat Akta Tanah (PPAT) dan memenuhi persyaratan sebagai berikut :

1) Tidak memuat kuasa untuk melakukan perbuatan hukum lain daripada membebankan hak tanggungan.

2) Tidak memuat kuasa substitusi.

3) Mencantumkan secara jelas objek hak tanggungan, jumlah hutang dan nama serta identitas krediturnya, nama dan identitas debitur apabila debitur bukan pemberi hak tanggungan.

b. Tidak dapat ditarik kembali atau tidak dapat berakhir oleh sebab apapun kecuali karena kuasa tersebut telah dilaksanakan atau karena telah habis jangka waktunya.

c. Surat Kuasa Membebankan Hak Tanggungan (SKMHT) mengenai hak atas tanah 
yang sudah terdaftar wajib diikuti dengan pembuatan Akta Pemberian Hak Tanggungan (APHT) selambat-lambatnya 1 (satu) bulan sesudah diberikan.

d. Surat Kuasa Membebankan Hak Tanggungan (SKMHT) mengenai hak atas tanah yang belum terdaftar wajib diikuti dengan pembuatan Akta Pemberian Hak tanggungan (APHT) selambat-lambatnya 3 (tiga) bulan sesudah diberikan.

Tata Cara Pembuatan Akta Pemberian Hak Tanggungan (APHT) yang dibuat dihadapan Pejabat Pembuat Akta Tanah (PPAT) terlebih dahulu harus adanya perjanjian pokok berupa Perjanjian Hutang Piutang, Perjanjian Kredit atau perjanjian sejenisnya yang kemudian diiringi dengan pembuatan Akta Pemberian Hak Tanggungan (APHT). Adapun langkah-langkah yang harus dilakukan oleh Pejabat Pembuat Akta Tanah (PPAT) adalah :

1) Meminta surat order.

Surat order adalah surat keterangan yang dikeluarkan oleh pihak bank yang berisi permintaan kepada Notaris/PPAT untuk melakukan pengikatan kredit dan pengikatan jaminan antara debitur dan kreditur serta antara pemberi hak tanggungan (penjamin) dengan penerima hak tanggungan (bank). Surat order merupakan dasar/awal dari segala kegiatan dalam proses pembuatan Akta Pemberian Hak Tanggungan (APHT)

Surat Order ini berisi antara lain :

a) Nama Debitur.

b) Jenis Fasilitas.

c) Jumlah plafond

d) Bunga Kredit.

e) Jangka Waktu Kredit

f) Provisi dan biaya administrasi.

g) Jaminan yang dijaminan oleh debitur/penjamin.

h) Permintaan pembuatan Akta Perjanjian Kredit (jika Notariil) dan Akta Pemberian Hak Tanggungan (APHT).

i) Waktu dan tempat pengikatan kredit dan jaminan.

j) Pihak yang menandatangai akta yaitu Pihak Bank, Debitur dan Penjamin.

k) Lampiran data-data pendukung.

2) Melakukan pengecekan sertifikat pada Kantor Pertanahan yang dilakukan dengan 2 (dua) tahap, yaitu :

a) Cek aman/cek intip

Cek aman dilakukan dengan menggunakan foto copy sertifikat yang gunanya untuk melihat status tanah. Disini akan terlihat apakan sertifikat aman, tidak bermasalah, tidak ada gugatan, tuntutan, sengketa dari pihak lain atau sertifikat dalam keadaan pemblokiran karena perkara di pengadilan. Pengecekan ini dapat ditunggu hasilnya.

b) Cek Fisik

Cek dengan menggunakan sertifikat asli. Gunanya

3) Meminta, melihat dan mengecek keaslian dari identitas para pihak yaitu berupa Kartu Tanda Penduduk (KTP), Surat Nikah dan Kartu Keluarga Debitur dan/atau Pemberi hak tanggungan (penjamin).

4) Foto copy KTP dan Surat Kuasa Direksi dari Penerima Hak Tanggungan dalam hal bank adalah penerima hak tanggungan atau kreditur.

5) Foto Copy SPPT PBB Tahun berjalan.

6) Meminta foto copy Perjanjian Kredit apabila dibuat dibawah tangan, apabila dengan akta notariil maka perjanjian kredit harus ditandatangani terlebih dahulu dari Akta Pemberian Hak Tanggungan (APHT).

Setelah semua persyaratan diatas sudah lengkap maka Pejabat Pembuat akta Tanah (PPAT) membuatkan Akta Pemberian Hak Tanggungan (APHT) sesuai dengan Peraturan Kepala Badan Pertanahan Nasional (Perkaban) Nomor 8 Tahun 2012 Tentang-Blangko-Akta-PPAT. Akta Pemberian Hak Tanggungan dibuat (APHT) 4 (empat) rangkap, dengan perincian sebagai berikut :

a) 2 (dua) rangkap asli ditandatangani diatas bermaterai Rp.6.000 yang ditandatangani oleh para pihak, saksi-saksi dan Pejabat Pembuat Akta Tanah (PPAT). 1 (satu) rangkap Lembar Pertama disimpan di Kantor Pejabat Pembuat Akta Tanah (PPAT) dan 1 (satu) rangkap lagi Lembar Kedua diserahkan kepada Kantor Pertanahan.

b) 2 (dua) rangkap salinan dimana 1 (satu) rangkap diserahkan kepada Kantor Pertanahan untuk pembuatan Sertifikat Hak Tanggungan berikut warkah-warkahnya dan 1 (satu) rangkap lagi diserahkan untuk pihak bank.

Pembuatan akta yang dilakukan oleh Pejabat Pembuat Akta Tanah (PPAT) harus disaksikan oleh sekurang-kurangnya 2 (dua) orang saksi Selanjutnya dilakukan pengikatan jaminan dihadapan Pejabat Pembuat Akta Tanah (PPAT), dimana Akta Pemberian Hak Tanggungan (APHT) wajib dibacakan dihadapan para pihak dan juga memberikan penjelasan mengenai isi dan maksud pembuatan akta pemberian Hak Tanggungan, dan prosedur pendaftaran ke Kantor Pertanahan. 
Menurut Pasal 101 Peraturan Menteri Negara Agraria/Kepala Badan Pertanahan Nasional Nomor 3 Tahun 1997 menyatakan :

(1) Pembuatan Akta Pejabat Pembuat Akta Tanah (PPAT) harus dihadiri oleh para pihak yang melakukan perbuatan hukum yang bersangkutan atau orang yang dikuasakan olehnya dengan surat kuasa tertulis sesuai dengan peraturan perundang-undangan yang berlaku.

(2) Pembuatan Akta Pejabat Pembuat Akta Tanah (PPAT) harus disaksikan sekurangkurangnya 2 (dua) orang saksi yang memuat ketentuan peraturan perundang-undangan yang berlaku. Pejabat Pembuat Akta Tanah (PPAT) wajib membacakan akta kepada para pihak yang bersangkutan dan memberi penjelasan mengenai isi dan maksud pembuatan akta, dan prosedur pendaftaran yang harus dilaksanakan selanjutnya sesuai dengan ketentuan yang berlaku.

Apabila objek Hak Tanggungan dalam keadaan sengketa maka menurut ketentuan Pasal 39 ayat (1) huruf (f) Peraturan Pemerintah Nomor 24 Tahun 1997 tentang Pendaftaran Tanah, Pejabat Pembuat Akta Tanah (PPAT) wajib menolak pemintaan untuk membuat Akta Pemberian Hak Tanggungan (APHT), apabila tanah yang akan dijadikan objek Hak Tanggungan dalam keadaan sengketa atau perselisihan. Karena pada umumnya Pejabat Pembuat Akta Tanah (PPAT) tidak mengetahui ada atau tidak sengketa pada tanah tersebut, maka Pejabat Pembuat Akta Tanah (PPAT) wajib menanyakan hal tersebut kepada pemberi Hak Tanggungan. Jika jawabannya tidak tersangkut dalam keadaan sengketa maka didalam Akta Pemberian Hak Tanggungan (APHT) perlu dicantumkan penyataan tersebut sebagai jaminan kreditur penerima Hak Tanggungan.

\section{B. Pelaksanaan Pendaftaran Akta Pemberian Hak Tanggungan (APHT) Pada Kantor Pertanahan.}

Pendaftaran hak tanggungan diatur dalam Pasal 13 sampai Pasal 14 Undang-undang Nomor 4 Tahun 1996 tentang Hak Tanggungan, Akta Pemberian Hak Tanggungan (APHT) yang dibuat oleh Pejabat Pembuat akta Tanah (PPAT) wajib didaftarkan. Secara sistematis tata cara pendaftaran dilakukan sebagai berikut :

1. Pendaftaran dilakukan di Kantor Pertanahan;

2. Pejabat Pembuat Akta Tanah (PPAT) dalam waktu 7 (tujuh) hari setelah ditandatangani Akta Pemberian Hak Tanggungan (APHT) maka Pejabat Pembuat Akta Tanah (PPAT) wajib untuk mengirimkan Akta Pemberian Hak Tanggungan (APHT) dan warkah lainnya kepada Kantor Pertanahan serta berkas yang diperlukan. Berkas itu meliputi :

a. Surat pengantar dari Pejabat Pembuat akta Tanah (PPAT) yang dibuat rangkap 2 (dua) dan memuat daftar jenis surat-surat yang disampaikan

b. Surat permohonan pendaftaran Hak Tanggungan dari penerima hak tanggungan ;

c. Foto copy identitas pemberi dan pemegang Hak Tanggungan ;

d. Sertipikat asli hak atas tanah atau hak milik atas satuan rumah susun yang menjadi objek Hak Tanggungan (yang sudah dibubuhi dengan catatan kesesuaian data yang ada di Kantor Pertanahan Kota Padang);

e. Lembar kedua Akta Pemberian Hak Tanggungan (APHT) ;

f. Salinan Akta Pemberian Hak Tanggungan (APHT) yang sudah diparaf oleh Pejabat Pembuat akta Tanah (PPAT) yang bersangkutan, untuk disahkan sebagai salinan oleh Kepala Kantor Pertanahan Kota Padang dalam pembuatan Sertipikat Hak Tanggungan ;

g. Bukti pelunasan biaya pendaftaran hak tanggungan.

3. Kantor Pertanahan membuatkan buku tanah hak tanggungan dan mencatatnya dalam buku tanah hak atas tanah yang menjadi objek hak tanggungan serta menyalin catatan tersebut pada sertifikat hak atas tanah yang bersangkutan.

4. Tanggal buku tanah hak tanggungan adalah tanggal hari ke tujuh setelah penerimaan secara lengkap surat-surat yang diperlukan bagi pendaftarannya dan jika hari ketujuh itu jatuh pada hari libur, maka buku tanah yang bersangkutan diberi tertanggal hari kerja berikutnya.

Di dalam Surat Menteri Negara/Kepala Badan Pertanahan Nasional Nomor.600-1035A, prihal persyaratan pendaftaran hak tanggungan, tertanggal 18 April 1996 yang ditujukan kepada Kakanwil BPN Propinsi dan Kakanwil Pertanahan Kabupaten/Kota seluruh Indonesia. Kelengkapan surat-surat/dokumen yang diperlukan untuk kelengkapan administrasi bagi tanah yang sudah bersertifikat atas nama pemberi hak tanggungan, yaitu :

a. Surat pengantar dari Pejabat Pembuat Akta Tanah (PPAT) yang bersangkutan.

b. Asli sertifikat hak atas tanah.

c. Asli Akta Pemberian Hak Tanggungan (APHT). 
d. Pelunasan biaya pendaftaran hak membuat buku tanah yang menjadi objek Hak tanggungan.

e. Bukti dipenuhinya persyaratan Tanggungan;

administrasi yang didasarkan pada minimal peraturan tertulis tingkat materi atau disetujui menteri.

Surat-surat/dokumen yang diperlukan bagi tanah sudah bersertifikat dan sudah ada akta peralihan haknya dan belum terdaftar ke atas nama pemberi hak tanggungan, yaitu :

a) Surat pengantar dari Pejabat Pembuat akta Tanah (PPAT) yang bersangkutan.

b) Asli sertifikat hak atas tanah.

c) Asli bukti terjadinya peristiwa/perbuatan hukum beralihnya hak atas tanah ke atas nama pemberi hak tanggungan, misalnya surat keterangan waris, atau akta pemindahan hak atas tanah.

d) Asli Akta Pemberian Hak Tanggungan (APHT).

e) Bukti dipenuhinya persyaratan teknik/administratif, misalnya apabila diperlukan untuk memenuhi PMA (Peraturan Menteri Agraria) Nomor.14 Tahun 1961.

5. Hak tanggungan lahir pada hari tanggal buku tanah hak tanggungan dibuatkan (Pasal 13 UUHT).

6. Kantor Pertanahan menerbitkan Sertifikat Hak Tanggungan. Sertifikat Hak Tanggungan memuat irah-irah dengan kata-kata "DEMI KEADILAN BERDASARKAN KETUHANAN YANG MAHA ESA". Sertipikat Hak Tanggungan mempunyai kekuatan eksekutorial yang sama dengan putusan pengadilan yang telah memperoleh kekuatan hukum tetap dan berlaku sebagai pengganti grosse acte Hypotheek sepanjang mengenai hak atas tanah. Kecuali apabila diperjanjikan lain, sertipikat hak atas tanah yang telah dibubuhi catatan pembebanan Hak Tanggungan dikembalikan kepada pemegang hak atas tanah yang bersangkutan.

Adapun mekanisme pendaftaran Hak Tanggungan yang dilakukan oleh Pejabat Pembuat akta Tanah (PPAT) ke Kantor Pertanahan adalah sebagai berikut:

a) Mendaftarkan pada loket pendaftaran;

b) Mengisi blanko permohonan pendaftaran;

c) Pemeriksaan keabsahan akta oleh kepala sub seksi peralihan, pembebanan hak, dan Pejabat Pembuat akta Tanah (PPAT);

d) Membayar biaya pendaftaran;

e) Proses pengerjaan berupa pengetikan blanko sertipikat Hak Hanggungan, mengisi atau

f) Salinan Akta Pemberian Hak Tanggungan (APHT) dijilid bersama sertipikat HakTanggungan;

g) Diserahkan pada kepala sub seksi peralihan, pembebanan hak dan Pejabat Pembuat akta Tanah (PPAT);

h) Akta asli yang bermaterai menjadi arsip buku tanah Hak Tanggungan;

i) Kemudian dikoreksi oleh kepala seksi pengukuran dan pendaftaran tanah dan diajukan kepada Kepala Kantor Pertanahan untuk ditandatangani;

j) Setelah penandatanganan oleh Kepala Kantor Pertanahan kemudian diberikan kepada petugas pembukuan dan ;

k) Sertipikat Hak Tanggungan sudah dapat diambil di Kantor Pertanahan oleh Pejabat Pembuat akta Tanah (PPAT) yang bersangkutan.

Mengingat pentingnya saat kelahiran hak tanggungan tersebut bagi kreditur oleh undangundang hak tanggungan ditetapkan secara pasti tanggal pembuatan buku tanah yang bersangkutan dalam Pasal 13 ayat (4) yang menyatakan tanggal tersebut adalah tanggal hari ketujuh setelah penerimaan secara lengkap suratsurat yang diperlukan bagi pendaftarannya dan jika hari ketujuh itu jatuh pada hari libur, buku tanah yang bersangkutan diberi tanggal pada hari kerja berikutnya.

Pelaksanaan pendaftaran Hak Tanggungan di Kantor Pertanahan berpedoman pada :

1) Undang-Undang Nomor 5 Tahun 1960 tentang Peraturan Dasar Pokok-Pokok Agrarian (UUPA).

2) Undang-Undang Nomor 4 Tahun 1996 tentang Hak Tanggungan Atas Tanah Beserta Benda-Benda YangBerkaitan Dengan Tanah.

3) Undang-Undang Nomor 5 Tahun 1996 tentang Pendaftaran Hak Tanggungan.

4) Peraturan Pemerintah Nomor 24 Tahun 1997 tentang Pendaftaran Tanah Juncto Peraturan Menteri NegaraAgraria/Kepala Badan Pertanahan Nasional Nomor 3 Tahun 1997

5) Peraturan Pemerintah Nomor 37 Tahun 1998 tentang Peraturan Jabatan Pejabat Pembuat Akta Tanah (PPAT).

C. Pelaksanaan Penghapusan Hak Tanggungan Pada Kantor Pertanahan.

Istilah Roya dalam Undang-undang Nomor 4 Tahun 1996 tentang Hak Tanggungan ditemukan dalam penjelasan umum butir 8 dan penjelasan Pasal 22 ayat (1) undang-undang ini. Kalau diperhatikan istilah roya dalam penjelasan 
undang-undang tersebut, roya memiliki arti pencoretan catatan tentang pembebanan hak tanggungan yang bersifat administratif di Kantor Pertanahan.

Adanya hak tanggungan karena adanya piutang yang dijamin pelunasannya apabila piutang itu hapus karena pelunasan atau sebab-sebab lain maka dengan sendirinya hak tanggungan menjadi hapus.

Permohonan pencoretan dilakukan oleh pihak yang berkepentingan dengan melampirkan, halhal sebagai berikut :

1. Sertipikat hak tanggungan yang telah diberi catatan oleh kreditur bahwa hak tanggungan hapus karena piutangnya telah lunas atau;

2. Pernyataan tertulis dari kreditur bahwa hak tanggungan telah hapus karena piutang yang dijamin dengan hak tanggungan telah lunas atau kreditur melepaskan hak tanggungan yang bersangkutan.

Bagi debitur yang telah melunasi hutang kepada kreditur dan ingin melakukan roya dengan syarat-syarat sebagai berikut :

$\begin{array}{lll}\text { 1) Surat } & \text { Permohonan } & \text { dari } \\ \text { debitur/pemegang } & \text { hak tanggungan } & \text { atau } \\ \text { kuasanya. } & & \end{array}$

2) Pengantar Roya dari kreditur

Debitur dapat memintakan kepada bank perihal pengantar roya apabila kreditnya telah lunas dan bank/kreditur berkewajiban untuk membuat pengantar roya untuk kepentingan debiturnya, meskipun bank sudah menerbitkan surat roya dan ternyata karena kelalaian debitur surat roya tersebut hilang maka bank dapat menerbitkan surat roya yang baru.

3) Sertifikat hak atas tanah objek hak tanggungan.

Apabila sertifikat atas tanah yang menjadi objek hak tanggungan hilang hal ini dapat dilakukan dengan penerbitkan sertifikat pengganti.

4) Sertifikat Hak Tanggungan.

Apabila sertifikat hak tanggungan maka dapat dilakukan dengan membuat Akta Konsen Roya yang dibuat dihadapan Notaris dengan ketentuan debitur harus melampirkan surat keterangan polisi mengenai kehilangan sertifikat hak tanggungan tersebut.

5) Tanda bukti pelunasan dari bank.

6) Bukti identitas permohonan roya.

7) Foto copy KTP atau identitas diri penerima kuasa yang disertai surat kuasa jika dimohonkan kuasa.

8) Kartu Keluarga Pemegang Hak Tanggungan.

9) Foto Copy SPPT PBB Tahun berjalan.

Berkas permohonan roya diserahkan oleh Pemohon kepada petugas loket Kantor Pertanahan untuk diperiksa kelengkapan persyaratan dan pembayaran biaya, selanjutnya petugas loket meneruskan berkas permohonan roya tersebut kepada Kepala Sub Seksi Peralihan, Pembebanan Hak dan Pejabat Pembuat akta Tanah (PPAT) untuk diperiksa kembali kelengkapan berkas dan selain itu juga diperiksa kesesuaian antara sertifikat tanah yang menjadi objek hak tanggungan dengan buku tanah yang terdapat di kantor Pertanahan. Apabila telah sesuai dan Kepala Sub Seksi Peralihan, Pembebanan hak dan Pejabat Pembuat Akta Tanah (PPAT) setuju untuk dilakukan roya maka dikirim berkas tersebut kepada pengetikan.

Setelah diketik berkas itu selanjutnya diserahkan kepada koordinator, setelah diparaf oleh koordinator, berkas tersebut dikembalikan kepada Kepala Sub Seksi Peralihan Pembebanan Hak dan Pejabat Pembuat akta Tanah (PPAT) untuk di paraf kembali, barulah diteruskan kepada Kepala Kantor Pertanahan untuk ditandatangani. Akhirnya sertifikat hak atas tanah diserahkan kembali ke loket Kantor Pertanahan sedangkan berkasnya disimpan sebagai warkah Kantor Pertanahan. Pemohon yang akan mengambil sertifikat hak atas tanahnya yang telah di roya melalui loket Kantor Pertanahan. 


\section{KESIMPULAN}

Berdasarkan uraian-uraian, maka dapat diambil kesimpulan yaitu :

1. Tata cara pembuatan Akta Pemberian Hak Tanggungan (APHT) yang dibuat dihadapan Pejabat Pembuat Akta Tanah (PPAT) adalah yang berisi pemberian hak tanggungan kepada kreditur sebagai jaminan untuk pelunasan piutangnya. Akta Pemberian Hak Tanggungan (APHT) adalah perjanjian assesoir/tambahan terhadap perjanjian pokok sehingga untuk pembuatan Akta Pemberian Hak Tanggungan (APHT) harus didahului dengan perjanjian pokoknya. Pembuatan Akta Pemberian Hak Tanggungan (APHT) bertujuan untuk mendaftarkan hak atas tanah yang dibebani hak tanggungan agar kepastian hukumnya terjamin baik kepastian subjek maupun objek haknya.

2. Pelaksanaan pendaftaran Akta Pemberian Hak Tanggungan (APHT) pada Kantor Pertanahan dilaksanakan oleh Pejabat Pembuat Akta Tanah (PPAT) tidak melebihi jangka waktu 7 (tujuh) hari. Pendaftaran Akta Pemberian Hak Tanggungan dimaksudkan untuk memberikan kepastian hukum antara pihak kreditur sebagai pemegang hak tanggungan dan pihak debitur sebagai pemberi hak tanggungan serta mudah dan pasti pelaksanaan eksekusinya.

3. Pelaksanaan penghapusan hak tanggungan pada Kantor Pertanahan adalah
Jika debitur telah melakukan pelunasan hutang, maka berarti bahwa perjanjian hutang-piutang diantara debitur atau pemberi hak tanggungan dan kreditur atau pemegang hak tanggungan telah berakhir untuk itu pelunasan pembayaran tadi harus diikuti dengan penghapusan Hak Tanggungan melalui pencoretan (roya).

\section{A. Saran-Saran}

1. Diharapkan Pejabat Pembuat Akta Tanah (PPAT) sebelum membuat Akta Pemberian Hak Tanggungan (APHT) harus bersifat hati-hati dan teliti dengan memperhatikan prosedur pembuatan, meneliti keabsahan data-data para pihak dan keabsahan sertifikat.

2. Diharapkan dalam pelaksanaan pendaftaran Hak Tanggungan di Kantor Pertanahan oleh Pejabat Pembuat akta Tanah (PPAT) tidak melebihi jangka waktu 7 (tujuh) hari kerja.

3. Diharapkan pada saat pengikatan jaminan dengan Akta Pemberian Hak Tanggungan (APHT), Pejabat Pembuat Akta Tanah (PPAT) memberikan kejelasan kepada para pihak mengenai prosedur dan akibat hukumnya mengenai pelaksanaan Roya apabila hutang-piutang telah dilunasi agar segera melakukan Roya pada Kantor Pertanahan. 


\section{Bibliography}

Budi Harsono, Hukum Agraria Nasional, Jilid 1, cetakan kesebelas, Djembatan, 2007.

Kansil, CST dan Christine ST. Kansil. Pokokpokok Hukum Hak Tanggungan Atas Tanah, Pustaka Sinar Harapan, Jakarta, 1997.

Kartini Muljadi Gunawan Widjaja, Hak Tanggungan, (Seri Hukum Harta Kekayaan), Kencana Prenada Media Group, Jakarta, 2005.

Kartini Soejendro, J, Perjanjian Peralihan Hak yang Berpotensi Konflik, Kanisius, Yogyakarta, Cet. Ke 4, 2001.

Kian Goenawan, Panduan Mengurus Izin Tanah dan Properti, Pustaka Grhatama, Yogyakarta, 2008.

Salim HS, Perkembangan Hukum Jaminan Di Indonesia, PT. Raja Grafindo Persada, Jakarta, 2004.

PT. Bank Danamon Indonesia, Tbk, Petunjuk Pelaksanaan Unit Legal, versiI.i. Jakarta, 2010.

Rachmadi Usman, Hukum Jaminan Keperdataan, Sinar Grafika, Jakarta, 2008.

Remy Sjahdeini, Hak Tanggungan, Asas-Asas, Ketentuan-Ketentuan Pokok dan Masalah Yang Dihadapi Oleh Perbankan (Suatu Kajian 